\title{
13 LANDFILL MANAGEMENT IN LITHUANIA
}

\author{
Ingrida Kavaliauskiene \\ Ministry of the Environment of the Republic of Lithuania
}

Lithuania

\begin{abstract}
There are about 680 small municipal waste landfills/ dumping sites with an area below 1 ha, about 120 medium-size landfills with an area of 1 to 5 ha and 35 large ( $>5 \mathrm{ha})$ landfills in Lithuania.

The majority of existing operational landfills fail to meet even basic environmental and sanitary-hygienic requirements.

Minister of Environment approved Rules for Setting Up, Operating, Closure and After-Care of Landfills of Waste in the year 2000. The procedure for the disposal of waste in landfills and the requirements for setting up, operating, closure and after-care of landfills so as to prevent or reduce as far as possible negative effects of landfills on the environment, particularly surface water and groundwater, soil and atmosphere, as well as any resulting risk to human health, have been defined in these rules.

Draft Strategic Plan of the Network of Landfills for Non-hazardous (Municipal) Waste prepared last year. The aim of this plan is to establish the procedure for closing down the existing landfills, site-conditioning operations and setting up new regional landfills (by developing regional municipal waste management systems) and to foresee the costs. It was calculated that in economic terms, taking into consideration costs of the transport of waste to landfills and the setting up, operating, closure and after-care of landfills, Lithuania would benefit most if it had 12 landfills.

Both documents mentioned above have been developed taking into consideration the requirements laid down by the European Union in the field of environmental protection and ensures the attainment of the targets laid down in the Directive on the Landfill of Waste $(1999 / 31 / \mathrm{EC})$.
\end{abstract}

\section{KEYWORDS}

Waste management, landfilling.

\section{REQUIREMENTS AND TARGETS OF THE EU DIRECTIVES}

The Framework Directive on Waste adopted in 1975 and amended in 1991 contains the requirement to implement the proximity and self-sufficiency principles which mean that generated wastes should be disposed at a nearest properly designed waste disposal facility and that the state should have a sufficient network of waste disposal facilities.

The Framework Directive on Waste adopted in 1975 and amended in 1991 contains the requirement to implement the proximity and self-sufficiency principles which mean that 
generated wastes should be disposed at a nearest properly designed waste disposal facility and that the state should have a sufficient network of waste disposal facilities.

The Directive on the Landfill of Waste adopted in 1999, lays down the following targets for conditioning operations of landfill sites:

- by the middle of 2002 , operators of landfills must prepare and present to the competent authorities conditioning plans for the sites including measures for ensuring full conformity of landfill sites with the requirements of the directive;

- all conditioning operations in all the existing landfills must be completed by mid2009 so that the landfills comply with the requirements of the directive or are closed down.

The Directive on the Landfill of Waste also lays down the following requirements:

- To reduce the amounts of biodegradable waste going to landfills.

- To ensure collection and use of gas from all landfills receiving biodegradable waste and collection and treatment of leachate.

- To close down landfills for which permits to continue operations have not been issued as soon as possible.

- To ensure that the price charged by the operator of the landfill for the disposal of any type of waste in that site covers all the costs involved in the setting up and operation of a landfill site, including as far as possible, the cost of the financial security or its equivalent which ensures that the obligations related to environmental protection and the planned closure procedures are fulfilled.

- While selecting a location for a landfill, to ensure the distance of at least $0.5 \mathrm{~km}$ to residential areas from landfills of non-hazardous waste. It is also necessary to take into consideration protection zones around water extraction sites, other restricteduse areas or protected areas, the geological and hydro-geological setting, etc. The landfill can be authorised only if the results of the environmental impact assessment (where such assessment is necessary under the Law on the Environmental Impact Assessment of Planned Economic Activities) indicate that the landfill does not pose a hazard to the environment.

- To prohibit disposal of certain wastes in landfills. Lists of wastes to be accepted and not acceptable in a landfill should be drawn up. The delivered waste must be weighed, inspected, registered and disposed according to the established procedure. The landfill must be fenced and guarded to prevent illegal dumping.

- Landfills for non-hazardous, hazardous and inert waste must be set up. Landfills of different classes must be subject to different requirements for landfill bottom and surface sealing, waste treatment and compacting, gas and leachate collection and treatment and environmental monitoring programmes. It is necessary to carry out after-care procedures following the closure of the landfill as long as the landfill poses a potential hazard to the environment.

\section{CURRENT WASTE MANAGEMENT SYSTEM}

\section{Generation of Waste}

The Ministry of Environment collects statistical data on waste generated and its management annually but this data is not fully reliable. Moreover, the existing database contains very little data on potential recyclables (e.g. paper, cardboard, glass, plastic) generated. Therefore, the assessment and estimation of the amounts of waste disposed in landfills is based both on statistical data accumulated by the Ministry of Environment and findings of additional 
research as well as experience of foreign countries (Table 1). The assessment of the amounts of waste to be landfilled in the future has taken into consideration population growth, the increase in the amount of waste per head of population and planned amounts of waste to be treated.

\begin{tabular}{|l|c|c|c|}
\hline County & $\mathbf{2 0 0 0}$ & $\mathbf{2 0 1 5}$ & Total 2000-2015 \\
\hline Alytus & 51.6 & 57.8 & 849.9 \\
\hline Kaunas & 209.3 & 233.0 & $3,434.8$ \\
\hline Klaipeda & 114.6 & 129.4 & $1,894.7$ \\
\hline Marijampole & 44.0 & 48.9 & $\mathbf{7 2 1 . 8}$ \\
\hline Panevèžys & 77.2 & 86.2 & $1,268.9$ \\
\hline Šiauliai & 100.5 & 112.9 & $1,657.3$ \\
\hline Tauragė & 27.8 & 30.9 & 456.2 \\
\hline Telšiai & 43.0 & 48.0 & 706.3 \\
\hline Utena & 46.5 & 51.9 & 764.3 \\
\hline Vilnius & 247.0 & 277.4 & $4,071.7$ \\
\hline Total & 961.5 & $\mathbf{1 , 0 7 6 . 4}$ & $\mathbf{1 5 , 8 2 5 . 9}$ \\
\hline
\end{tabular}

Table 1. Amounts of Waste Disposed in Landfills (thousands of tonnes)

\section{Waste Collection and Disposal in Landfills}

The main methods of waste collection used in Lithuania:

- collection without the use of containers

$10-30 \%$;

- collection into containers

$60-70 \%$;

- delivery to landfills by own means

$10-20 \%$.

Some towns and district centres collect secondary raw materials (waste paper, glass, plastic, metals) into separate containers. The number of existing containers allocated for collecting secondary raw materials is adequate in many locations, however, the quality of collected secondary raw materials is poor. All companies that collect secondary raw materials face financial problems, since companies that process these secondary raw materials pay low prices for poor-quality recyclable materials and there are no other sources of financing. Furthermore, processing companies frequently refuse to accept poor-quality secondary raw materials collected in containers for secondary raw materials. Thus, secondary raw materials often go to landfills.

There are about 680 small municipal waste landfills/ dumping sites with an area below 1 ha, about 120 medium-size landfills with an area of 1 to 5 ha and 35 large ( $>5$ ha) landfills. Waste is currently disposed in more than 300 landfills, i.e. one landfill serves a territory with 10,000 inhabitants on average (in Western Europe, one landfill usually services a territory with more than 100,000 inhabitants). 3,105 thousand tonnes of waste was delivered to landfills in 1999 (including waste generated in industrial enterprises during the technological process, such as phosphogypsum waste, etc.). 
The largest amounts of unsorted municipal waste were disposed in the following landfills:

- Vilnius city Kariotiškès Landfill (199,199 t);

- Kaunas town landfill in Lapes village $(118,983 \mathrm{t})$;

- Klaipèda town landfill in Kalotè village $(86,485 \mathrm{t})$;

- Panevėžys town landfill in Liūdynè village $(65,432 \mathrm{t})$;

- Šiauliai town landfill in Kairiai village $(61,885 \mathrm{t})$.

\section{Legal-Institutional Framework}

Law on Waste Management approved in 1998 and the Rules on Waste Management approved by Order No. 217 of 14 July 1999 of the Minister of Environment lay down the main principles for organising a waste management system that are in line with the European Union requirements.

Industrial enterprises are responsible for the management of industrial waste listed in the authorisations for the use of natural resources. The responsibility for management of other types of waste lies with local authorities, however, industrial enterprises have the right to decline to use municipal waste management systems and to handle their waste themselves.

The procedure for the disposal of waste in landfills and the requirements for setting up, operating, closure and after-care of landfills so as to prevent or reduce as far as possible negative effects of landfills on the environment, particularly surface water and groundwater, soil and atmosphere, as well as any resulting risk to human health, have been defined in the Rules for Setting Up, Operating, Closure and After-Care of Landfills of Waste approved by Decree No. 444 of 18 October 2000 of the Minister of Environment. These rules have been prepared on the basis of the Landfill Directive.

Local authorities organise the setting up, operation and closure of landfills within their territories. By November 2002, local authorities, together with operators of existing landfills and economic entities that hold and operate landfill sites, must prepare conditioning plans for existing landfill sites. These plans should provide for site-conditioning operations to ensure that, till the end of the year 2011, landfill sites will meet the requirements defined in the Rules for Setting Up, Operating, Closure and After-Care of Landfills of Waste, or should foresee the closure of these sites.

Draft Strategic Plan of the Network of Landfills for Non-hazardous (Municipal) Waste prepared last year. The provisions of this Strategic Plan of the Network of Landfills for NonHazardous (Municipal) Waste (hereinafter the Plan) are planned to be transposed to the National Strategic Waste Management Plan.

The aim of the Plan is to establish the procedure for closing down the existing landfills, siteconditioning operations and setting up new regional landfills (by developing regional municipal waste management systems) and to foresee the costs.

The Plan has been developed taking into consideration the requirements laid down by the European Union in the field of environmental protection and ensures the attainment of the targets laid down in the Directive on the Landfill of Waste (1999/31/EC).

\section{PROBLEMS OF WASTE DISPOSAL IN LANDFILLS}

\section{Information on Waste Disposal in Landfills}

The Landfill management strategy is inseparable from the general waste management strategy. To ensure proper management of landfills, it is necessary to solve the issues related to waste prevention and minimisation, sorting, collection, transport and recovery of waste. 
Reliable data on the amounts and composition of waste (secondary raw materials) is needed. The current data available on the generation of waste and its composition is unreliable and inaccurate. Data on the generation of municipal waste is based on a visual assessment of the amount of landfilled waste in cubic metres that is subsequently converted into tonnes. Waste is weighed in a very limited number of municipal waste landfill sites. Therefore, data presented in the draft Strategic Plan of the Network of Landfills for Non-hazardous (Municipal) Waste is more based on the data of additional research and expert assessments rather than the available statistical data.

Local authorities organise the setting up, operating, closure and after-care of landfills within their territories, however, they do not have detailed information on existing landfills, the amounts of waste landfilled and its composition. The available data is not enough to enable local authorities to plan and implement municipal waste management systems effectively.

\section{Setting up and Operating Landfills}

The majority of existing operational landfills fail to meet even basic environmental and sanitary-hygienic requirements:

- locations for landfill sites have been chosen without taking into consideration the specific environmental impact of these facilities and without carrying out a comprehensive assessment of the natural setting and socio-economic conditions. The distance between landfills and people's houses in some locations is less than 500 metres. Some landfills are set up in protected areas, in the protection zones of water extraction sites or forests;

- abandoned gravel, sand and clay quarries or natural pits without any engineering facilities are frequently used for waste disposal;

- landfill bottom sealing or surface sealing following the closure of the landfill is not properly designed or not carried out at all;

- inclinations of landfill slopes are inappropriately formed, frequent slippages, erosion;

- landfill leachate is collected and treated in a limited number of landfills;

- there are no landfill gas collection and treatment systems;

- landfills are operated inappropriately: the requirements to cover landfills with soil are not implemented, waste sections in landfills are formed inappropriately or not formed at all, waste is usually discharged in a large area, shoved with a bulldozer and only slightly compacted. Discharged waste in rural areas is shoved by a bulldozer only a few times per year and partially covered with soil;

- insufficient control of landfilled waste: hazardous wastes, e.g., batteries, electric cells, oil-contaminated soil as well as waste that can used, e.g., biodegradable waste of park and garden cleaning works, used tyres, etc. go to landfills for municipal waste;

- there are no weighing facilities or they are insufficient, the accounting of landfilled waste is not reliable. Sometimes landfilled waste is not accounted at all;

- landfills are not fenced, unauthorised persons who collect secondary raw materials: papers, glass containers, soft drinks and beer cans, scrap metal and articles used in households can gain access to landfills;

- monitoring of the surrounding areas of landfills is not implemented;

- after-care of landfills is not performed. 


\section{Management of Waste Management Systems}

There is no institution on the state level that would be responsible for the regulation of the of public utilities, including management of municipal waste.

Local authorities do not actually set tasks for companies handling municipal waste and do not control their activities. Different firms collect the largest part of high-quality secondary raw materials, especially paper and cardboard (the collection of which is profitable) without notifying local authorities, whereas the companies operating according to the requirements of municipal waste management systems are left with low-quality secondary raw materials the collection of which produces additional costs. This results in higher costs of municipal waste management systems and creates the need for additional financing, whereas firms collecting high-quality secondary raw materials are actually making profit at the expense of inhabitants.

Waste sorting, recycling and disposal plants are rather complex and their installation and operation produces significant costs, therefore, they cannot be acquired by all the municipalities. Furthermore, the cost-effectiveness of these plants depends on their size: only high-capacity plants produce benefits in terms of cost-effectiveness. Aiming to develop effective waste management systems, municipalities must co-operate and establish economically profitable waste sorting, recycling and disposal companies.

Under the existing laws, co-operation of municipalities can be implemented only in a few ways. They can set up public companies or public institutions or join associations that could establish waste management companies themselves or hire private companies by way of tender.

There is a need for a detailed analysis of the co-operation possibilities for municipalities and, if needed, to put forward needed amendments of existing legal acts or present new draft legal acts that would give municipalities the possibility of developing effective waste management systems jointly.

\section{Financing}

Under the current practice, companies that collect waste conclude waste collection contracts with residents or their associations, companies and organisations. Contracting and execution of contracts is a complex procedure. In the majority of municipalities about 30 percent of waste holders do not conclude such contracts and do not pay for waste management services. The tariffs for waste management services in different municipalities vary and range from 1 to 3 and more litas for one inhabitant per month. The average tariff, that amounts to $1.5-2$ litas per inhabitant per month, covers only a small part of the costs involved in setting up and operating a landfill. Local authorities do not include the costs of the collection of secondary raw materials, therefore, these activities start producing losses to companies.

The highest tariff per tonne of waste accepted in a landfill is approximately 20 litas. When setting up new landfills (mineral liner, leachate collection system consisting of insulating membrane and drainage layer, gas collection system) and applying higher requirements for the operation of landfills, the said tariff would have to be raised 3 to 5 times to cover all landfill set-up and operating costs.

A very large amount of waste fit for recycling is generated after the expiry of the shelf-life of products, especially packaging. Handling of this waste should be the responsibility of producers, however, they are not involved in waste management activities. Draft Law on the Amendment of the Law on Pollution Charges to include product charges approviding for the responsibility of producers have been developed, however, it have not been adopted yet. 


\section{STRATEGIC PLAN OF THE NETWORK OF LANDFILLS FOR NON-HAZARDOUS WASTE}

\section{Construction of New Landfills}

Efforts to define the optimal number of landfills for municipal waste took into consideration the amount of municipal waste generated in each county, the costs of their transport from generation sites to landfills and the costs of designing, constructing, setting up, operating and after-care of landfills. Assessment was performed in each county of Lithuania. Options of having one or two municipalities of a neighbouring county joined into one waste disposal system have also been analysed.

In every case, calculations have shown that general transport and disposal prices are more favourable under those options that provide for a smaller number of landfills to be located in a county. In economic terms, taking into consideration costs of the transport of waste to landfills and the setting up, operating, closure and after-care of landfills, Lithuania would benefit most if it had 12 landfills.

The final territorial distribution and number of landfills can be different. This may be determined by the possibilities to choose a suitable land plot, waste transport conditions, particular requirements for setting up landfill operating companies and other factors. Thus, a feasibility study must be carried out in every case to assess natural, economic and social conditions and to put forward alternative technical solutions.

\section{Closure of Existing Landfills}

According to the requirement of the Rules for Setting up, Operating, Closure and After-Care of Landfills of Waste, municipal institutions, together with operators of existing landfills and economic entities that own and operate landfills, must develop and agree with Regional Environmental Protection Departments of the Ministry of Environment site-conditioning plans for existing landfills by the end of 2002. These plans should foresee landfill conditioning operations to ensure that they meet all the defined requirements or are closed or restored by the end of 2011 .

It is necessary to analyse all the existing landfills and to assess their potential impact on the environment and human health, to assess the quality of their design, construction and operation, the degree to which they are filled up and other conditions. Landfills situated in protected areas and in geologically highly vulnerable areas and large landfills filled up with waste must be closed down first.

The existing landfills, even small ones, cannot be closed immediately before the collection of waste and its transport to other landfills ready to accept waste is organised. Therefore, there are plans to implement the necessary waste collection infrastructure while constructing new regional landfills. Following the introduction of regional waste management systems, the operation of existing landfills that do not meet the established requirements will have to be terminated, however, their restoration and final conditioning operations can be planned up to the end of 2011.

Municipalities, which refuse to participate in the implementation of regional waste management systems, will have to complete site-conditioning operations in all operating landfills located within their territory according to the defined requirements before regional systems, which these municipalities were invited to join start functioning. 


\section{Cost Assessment}

\section{Construction of New Landfills}

The price of waste disposal in landfills is determined by many factors: characteristics of the location chosen for a landfill, costs of landfill design, construction, operating and after-care, the distance of the transport of waste from its generation site to the landfill, vehicles and equipment used, work organisation, etc. When larger landfills are set up, total relative costs of waste disposal decrease, although the reduction of the number of landfills increase the distances of waste transportation, which, in its turn, increases the transportation costs.

Setting up modern landfills (research, design, construction, acquisition of equipment) requires significant investments. Calculations have been made showing that setting up the proposed 12 municipal waste landfills (not including waste collection, sorting, transport infrastructure and composting, sorting, construction waste sites as well as building of roads to the landfills) would require approximately 200 million Lt over 11 years, 20.5 million Lt per year would be required for operating the landfills and closure and after-care would require about 90 million Lt.

The costs of reconstruction and enlargement of the operating landfills may differ from the construction costs of a new landfill. The better the compliance of the existing landfill with the requirements, the less investments will be needed for its reconstruction. In the case of reconstruction and enlargement of a landfill, there might be no need to solve ownershiprelated issues, build access roads, install energy and communication lines or build administrative or other facilities, etc. However, since the majority of landfills require additional environmental measures and since their period of operation is coming to an end and they do not meet the essential requirements, it is likely that landfill reconstruction costs will not be much different from the costs of setting up newly constructed landfills.

\section{Closure of Existing Landfills}

The costs of the closure and restoration of a landfill depend not only on the size of the landfill but on the composition of waste disposed there, local conditions of the landfill and on the selected restoration technology. In landfills where large amounts of organic waste are disposed and the biodegradation process is not complete, there might be a need to install drainage systems for leachate and gas collection and to construct and operate leachate and gas treatment plants. If tests of the condition of the landfill showed that leachate contaminates underground water of the aquifer used, it might be necessary to employ costly measures for improving the quality of underground water and eliminating pollution. The restoration of 1 hectare of such problematic landfills would cost about 1 million Lt. Estimated restoration costs of all the existing landfills amount to approximately 270 million litas.

Following the restoration of a landfill, as long as the landfill poses a potential hazard, an aftercare period is needed. Such a period may last about 30 years and requires significant amounts of funding which make up approximately 45 percent of the landfill construction cost.

\section{Financing}

It is intended to implement the Strategic Plan of the Network of Landfills for Non-Hazardous (Municipal) Waste by introducing regional waste management systems. The EU Accession Programme for 2000 - 2003 of the Republic of Lithuania approved by Minutes No 26 of the meeting of 24 May 2000 of the Government of the Republic of Lithuania stipulates that 
regional municipal waste management projects will be given priority in the field of waste management: priority will be given to regional municipal waste landfills and collection systems serving 4 and more municipalities. Consideration would be given to the hazards to the environment posed by the existing landfills by focusing on the closure of the largest landfills.

In order to implement each project of a regional waste management system, funds will be used according to the following principle:

$50 \%$ : the ISPA Fund;

$20 \%$ e Lithuanian funds (state and municipal budgets, money of private persons, etc.); $30 \%$ : State-guaranteed loan.

For every project foreseen in the programme, a feasibility study, including the selection of a waste management system most acceptable to the respective region and a detailed assessment of the need for investments, will be prepared alongside with other documents necessary for receiving the ISPA grant for the preparation of which financial and technical assistance from the European Union member states will be available.

The financing needs for the construction of new landfills and closing down the existing landfills over fifteen years assessed in the Strategic Plan the amount to approximately 470 million litas, however, by implementing ISPA-financed projects it would be possible, by the year 2006, to close down only a few largest and most problematic landfills and to set up only a few sections of each new landfill, whereas funds for further development of landfills must be included in the tariffs of waste disposal in landfills.

Assistance of international funds and funds of the State budget are planned for implementing plans of landfill closure and restoration developed by municipalities and agreed with Regional Environmental Protection Departments of the Ministry of Environment.

\section{References}

1. Rules for Setting Up, Operating, Closure and After-Care of Landfills of Waste approved by Decree No. 444 of 18 October 2000 of the Minister of Environment (Valstybes ziniose 2000, Nr. 96-3051)

\section{Draft Strategic Plan of the Network of Landfills for Non-Hazardous (Municipal) Waste}

3. Council Directive 1999/31/EC of 26 April 1999 on the landfill of waste (Official Joumal of the European Communities, 16. 7. 1999)

4. Law on Waste Management of the Republic of Lithuania approved by the Seimas 16 June 1998, No VIII-787 (skelbtas Valstybes ziniose 1998, Nr 61-1726) 